\title{
'TAM Mild Habanero,' a Low-pungency Habanero Pepper
}

\author{
Kevin M. Crosby ${ }^{1}$ \\ Texas Agricultural Experiment Station, 2415 East Highway 83, Weslaco, Texas \\ 78596
}

Daniel I. Leskovar

Texas Agricultural Experiment Station, 1619 Garner Field Road, Uvalde, Texas 78801

\section{Kil Sun Yoo \\ Texas A\&M University, Department of Horticultural Sciences, Vegetable and Fruit Improvement Center, 1500 Research Parkway, Suite 120, College Station, Texas 77845}

Additional index words. Capsicum chinense, capsaicin, germplasm, open-pollinated

The Texas Agricultural Experiment Station (TAES) at Weslaco announces the release of 'TAM Mild Habanero,' (TMH) a high yielding, low pungency Habanero pepper (Capsicum chinense Jacq.). The project to breed improved peppers at the TAES began in 1971. Several cultivars of chile peppers, including two mild jalapeños have been released over the last 20 years(Crosby and Villalon, 2002; Villalon, 1983; Villalon etal. 1992, 1994). Production of hot and sweet peppers in Texas has fluctuated from 1,200 to 7,000 ha over the last 30 years. Currently, close to 1,700 ha are cultivated statewide.

The Habanero pepper, a distinct cultigen of Capsicum chinense, has become increasingly popular in American markets due to its unique flavor and aroma. It has gained notoriety also for its extremely high pungency level, with capsaicin concentrations far in excess of other commonly cultivated hot peppers. This attribute has also restricted its use in fresh salsas, pickles and other food preparations, which require significant proportions of the pepper product to achieve desired flavors. The development of the 'TAM Mild Jalapeño' and subsequent mild versions of that pepper cultigen proved that genetic components, which condition important flavor compounds, could be maintained in the absence of genes involved in capsaicin synthesis. Research at the TAES demonstrated some linkage between these genes, requiring intensive selection in large breeding populations to identify individual plants producing fruit with good aroma and flavor and low capsaicin concentrations. The same process has now been successfully completed with the Habanero pepper.

Received for publication 27 July 2004. Accepted for publication 29 Sept. 2004. Research conducted at the Texas Agricultural Experiment Station, Weslaco, Texas. Use of tradenames does not imply endorsement of the products named nor criticism of similar ones not named.The authors thank Rick Hernandez, Kay Harding, andAlfredo Rodriguez for theirvaluable help in conducting greenhouse and field experiments.

${ }^{1}$ Assistant professor, corresponding author: kcrosby@tamu.edu.

\section{Origin}

Seed of PI 543188 was received from the USDA Plant Introduction Station, Griffin, Ga. The descriptors for this $C$. chinense accession were low pungency and small fruit. When planted in the greenhouse at Weslaco the seed yielded predominantly pungent, $C$. апnиит types and only two apparent $C$. chinense plants. One of these plants had small, yellow, nonpungent fruit, while the other had pungent, red fruit. An initial cross was made between the nonpungent selection out of PI 543188 and a highly pungent, typical orange Habanero pepper from Yucatan selected for high yield. $F_{1}$ plants of the cross were allowed to selfpollinate in the greenhouse to produce the $\mathrm{F}_{2}$ generation. This $\mathrm{F}_{2}$ population was evaluated in the field at Weslaco under commercial

Fig. 1. Fruit of 'TAM Mild Habanero'(left) compared to 'Yucatan Habanero' (right).
Table 1. Comparison of yield and fruit quality traits between 'TAM Mild Habanero' (TMH) and 'Yucatan Habanero' (YH). W = Weslaco, $\mathrm{U}=$ Uvalde.

\begin{tabular}{lcc}
\hline Trait & TMH & YH \\
\hline Fruit color & Yellow & Orange \\
Lightness $(\mathrm{L})^{\mathrm{z}}$ & $60.5 \mathrm{a}^{\mathrm{y}}$ & $57.6 \mathrm{a}$ \\
Chroma $(\mathrm{C})$ & $58.1 \mathrm{a}$ & $54.2 \mathrm{a}$ \\
Hue angle $\left(\mathrm{H}^{\circ}\right)$ & $82.8 \mathrm{a}$ & $65.3 \mathrm{~b}$ \\
Days to maturity & $86 \mathrm{~b}$ & $100 \mathrm{a}$ \\
Fruit size $(\mathrm{W}) \mathrm{g}$ & $13.1 \mathrm{a}$ & $12.4 \mathrm{a}$ \\
Fruit size $(\mathrm{U}) \mathrm{g}$ & $7.4 \mathrm{a}$ & $7.5 \mathrm{a}$ \\
Yield $(\mathrm{W}) \mathrm{kg} / \mathrm{ha}$ & $10,691 \mathrm{a}$ & $8,607 \mathrm{~b}$ \\
Yield $(\mathrm{U}) \mathrm{kg} / \mathrm{ha}$ & $16,299 \mathrm{a}$ & $10,258 \mathrm{~b}$ \\
Total capsaicin $(\mathrm{W}) \mu \mathrm{g} \cdot \mathrm{g}^{-1}$ & $154 \mathrm{~b}$ & $12,704 \mathrm{a}$ \\
Scoville Units & $2,310 \mathrm{~b}$ & $190,560 \mathrm{a}$
\end{tabular}

${ }^{2}$ Lightness $(+100=$ white, $-100=$ black $)$, Chroma (intensity) and Hue angle $\left(0^{\circ}=\right.$ red-purple, $90^{\circ}=$ yellow, $180^{\circ}=$ bluish-green, $270^{\circ}=$ blue)

${ }^{y}$ Mean separations within rows by LSD, $P \leq 0.05$. Means followed by the same letter are not significantly different.

${ }^{x}$ Based on 6 week-old transplants.

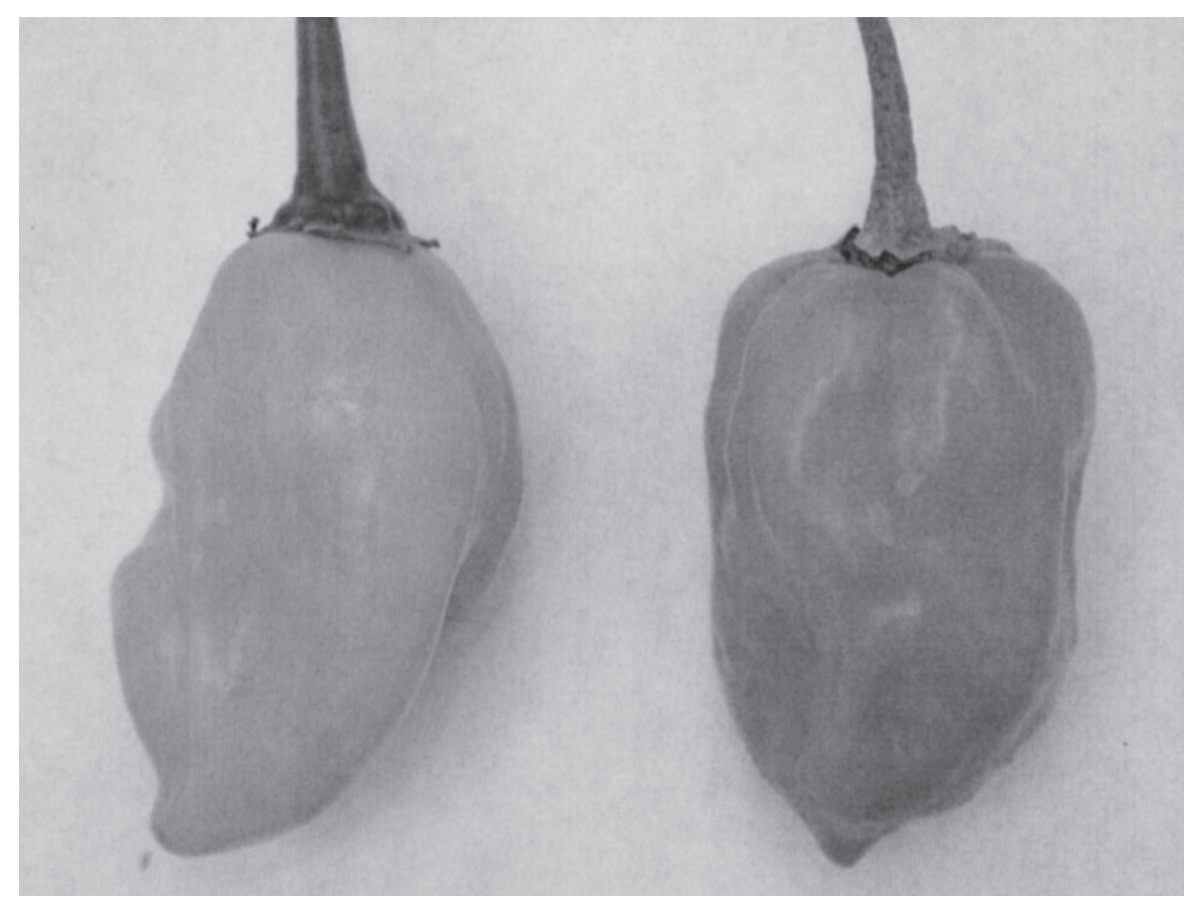


field practices, including drip irrigation and chemical pest control. A single plant selection with high yield and no detectable pungency was selected as a pollen parent to backcross to 'Yucatan Habanero' (YH). Plants of this $\mathrm{BC}_{1}$ seed were established in a field plot and allowed to sib- and self-pollinate. This bulk seed was planted again in the field and selfpollinated seed of eight single plant selections with extremely low-pungency were collected. These lines were again planted in the field and one line, 466-54, was selected for its uniformity, high yield, earliness and large, highly aromatic fruit. The three best plants from this line were moved to the greenhouse and selfpollinated by hand. The seed was planted in field isolation plots and the line 466-54-36 was chosen as the best for fruit quality and yield characteristics. This line was subsequently planted in field isolation plots for an additional three generations to collect yield and quality data. This process of inbreeding resulted in a highly uniform, novel cultivar-'TAM Mild Habanero.' Uniformity was excellent for low pungency, yield and earliness.

\section{Description}

Replicated field trials were conducted at Weslaco, on a Hidalgo sandy loam soil, and Uvalde, on a silty clay soil, using drip irrigation and commercial production practices. Table 1 compares fruit and quality traits of $\mathrm{TMH}$ and $\mathrm{YH}$ at these two locations. The fruit of TMH is very similar in size and shape to the recurrent parent (Fig. 1). Color is yellow-orange as opposed to the deep orange of 'Yucatan Habanero,' but aroma and flavor are extremely similar to the hot parent. Using a chromameter (CR-200; Minolta Corp., Ramsey, N.J.), lightness $(\mathrm{L})$, chroma $(\mathrm{C})$, and hue angle $\left(\mathrm{H}^{\circ}\right)$ measurements were taken for comparison. The major difference was the higher hue value for $\mathrm{TMH}$, indicating more yellow than $\mathrm{YH}$ (Table 1). The fruit of TMH matured $10 \mathrm{~d}$ earlier than those of $\mathrm{YH}$ at Weslaco, a commercially important trait for fall production.

Plants of TMH grown with subsurface drip irrigation at Weslaco produced significantly

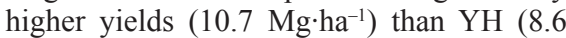
$\left.\mathrm{Mg} \cdot \mathrm{ha}^{-1}\right)$. TMH also out-yielded YH at Uvalde

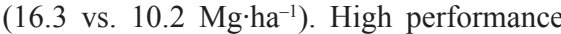
liquid chromatography was used to measure total capsaicin and carotenoid concentrations in fruit samples from Weslaco (Hoffman et al., 1983). Total capsaicin concentration of $\mathrm{TMH}$ fruit at Weslaco averaged $154 \mu \mathrm{g} \cdot \mathrm{g}^{-1}$, compared to $12,704 \mu \mathrm{g} \cdot \mathrm{g}^{-1}$ for the YH. Total capsaicin (dry weight basis) was converted to Scoville Heat Units (SHU) following the method of Collins et al. (1995). Additionally, mature fruit of TMH had significant levels of beta-carotene at $7.6 \mu \mathrm{g} \cdot \mathrm{g}^{-1}$, while those of YH had no detectable beta-carotene.

\section{Availability}

Breeder's seed will be maintained by the Texas Agricultural Experiment Station at Weslaco. Application for a plant variety protection patent is being filed for 'TAM Mild Habanero.' This open-pollinated cultivar may be licensed through the Texas Agricultural Experiment Station, for commercial seed production.

\section{Literature Cited}

Collins, M.D., L.M. Wasmund, and P.W. Bosland. 1995. Improved method for quantifying capsaicinoids in Capsicum using high-performance liquid chromatography. HortScience 30:137-139.

Crosby, K.M. and B. Villalon. 2002.'TAM Mild Jalapeño II,' a new, multiple virus resistant, mild jalapeño pepper. HortScience 37:999-1000.

Hoffman, P.G., M.C. Lego, and W.G. Galetto. 1983. Separation and quantification of red pepper major heat principles by reverse-phase high-pressure liquid chromatography. J. Agr. Food Chem. 31:1326-1330.

Villalon, B. 1983. TAM mild jalapeño pepper-1 pepper. HortScience 18: 492-493.

Villalon, B., F.J. Dainello, and D.A. Bender. 1992. 'TAM Veracruz'hotjalapeño pepper. HortScience 27:184-185.

Villalon, B., F.J. Dainello, and D.A. Bender. 1994. 'Jaloro' hot yellow jalapeño pepper. HortScience 29:1092-1093. 